\title{
Physicochemical, thermal and rheological properties of three native corn starches
}

\author{
Juan Carlos BUSTILLOS-RODRÍGUEZ¹, Juan Manuel TIRADO-GALLEGOS ${ }^{1}$, Magali ORDÓÑEZ-GARCÍA, \\ Paul Baruk ZAMUDIO-FLORES ${ }^{1}$, José de Jesús ORNELAS-PAZ ${ }^{1}$, Carlos Horacio ACOSTA-MUÑIZ1, \\ Gabriel GALLEGOS-MORALES ${ }^{2}$, Delia Esther PÁRAMO-CALDERÓN ${ }^{3}$, Claudio RIOS-VELASCO ${ }^{1 *}$
}

\begin{abstract}
Native starch was isolated from two corn landraces (blue and white) and a hybrid variety and then characterized for its physicochemical, thermal and rheological properties. The hybrid variety showed the highest starch yield, with its starch showing the highest fat, moisture and protein content but the lowest onset temperature of gelatinization. The hybrid corn starch also showed the highest $G$ ' and $G$ " values. The tested starches showed similar $T_{p}, T_{c}$, and $\Delta H$ values. The amylose contents ranged from 21.5 to $22.4 \%$, with starch from blue corn showing the highest amylose content. All starches were white, with $L$ values ranging from 93.6 to 99.5. The light absorbance of the starch gels increased with storage time. The obtained results demonstrated that the physicochemical, thermal and rheological properties of corn starch are highly dependent on the corn type.
\end{abstract}

Keywords: corn type; maize; polysaccharides; functionality; technological uses; bromatological composition.

Practical Application: The innovations of this study are to characterize the main properties of three native corn starches, which give them various technological applications, to be used in various industrial processes, whether food or non-food.

\section{Introduction}

Corn, Zea mays L. (Poales: Poaceae), is the second most important grain crop worldwide in terms of production and consumption. Several corn landraces and hybrids are cultivated in Mexico, with the latter being currently preferred due to their high yield, resistance to pests and hydric stress, and nutritional value (Food and Agriculture Organization of the United Nations, 2016; Uarrota et al., 2013). Corn is used as human food, cattle feed and as a source of several industrial products and sub-products, such as starch, which is a polysaccharide that accumulates as granules of different sizes, shapes and composition and represents 86 to $89 \%$ of the grain endosperm (Agama-Acevedo et al., 2005; Eliasson, 2004). It is composed of two homopolysaccharides of glucose, amylose and amylopectin, with linear and branched structures, respectively (Liu et al., 2002). Recently, there has been increasing interest in the use of starch as a functional ingredient in many food and non-food applications, because it can modify physicochemical, thermal, and rheological properties (Bello-Pérez et al., 1999; Waterschoot et al., 2015). Starch is commonly used as a film-forming ingredient as several studies have demonstrated that starch is particularly useful for the elaboration of biodegradable or edible films, reducing the use of conventional materials based on fossil sources and, consequently, environmental pollution (García et al., 2009). The high availability of corn starch makes possible this type of alternative use. However, the yield and properties of corn starch appear to depend on its source hybrid or landrace type (Idikut et al., 2009; Zehr et al., 1995). Undoubtedly, physicochemical variations in starch properties might alter the functionality of this polysaccharide. Starch contributes to the textural properties of many products as a gelling agent, thickener, adhesive, colloidal stabilizer and water retention agent (Singh et al., 2003). Approximately 60 million tons are extracted annually worldwide from various cereal, tuber and root crops (Copeland et al., 2009). Corn starch makes up more than $80 \%$ of the world market for starch (Jobling, 2004). Mexico is the center of origin and diversity of corn varieties, with more than 60 varieties and sub-varieties recognized; however, only a few have been characterized with respect to their starch content and functional properties (Álvares-Buylla, 2004). Currently, a number great of corn types have developed by different process in which these corns have undergone changes over time mainly in the structure and composition of the grain due to continual mutations, hybridizations, segregations and selections by human and by natural processes, among other (Eckhoff \& Watson, 2009; Smith, 2004). The development of corn hybrids has been considered as the most important genetic change in corn for starch production (Eckhoff \& Watson, 2009). The functional properties of corn hybrids, could have a potential use in the industry to obtain some products such as starch, flour, corn syrup or dextrose, pureed grain, corn oil, ethanol, paper and charcoal (Acton, 2013; Cauvain \& Young, 2009; 
Eckhoff \& Watson, 2009), possibly with better performance in some of these applications than corn landraces. Thus, the aim of this study was to evaluate the content and physicochemical, thermal, and rheological properties of starch isolated from two corn landraces and a hybrid variety.

\section{Materials and methods}

\subsection{Materials}

Grains of blue and white corn landraces and a hybrid corn variety (Pioneer P1879, Pioneer-DuPont Company) were harvested in 2015 from a commercial field in Cuauhtemoc, Chihuahua, Mexico. The harvesting areas for the blue, white and hybrid corn were located 2,000 and 2,200 masl, respectively. The chemical reagents (analytical grade) were purchased from Sigma Aldrich (Toluca, Estado de Mexico, Mexico) unless stated otherwise.

\subsection{Starch isolation}

Starch was isolated according to Wang \& Wang (2001) and Sandhu et al. (2004). Corn grains were finely ground using a hand mill. One kilogram of milled corn was mixed with $2 \mathrm{~L}$ of $0.1 \%$ $\mathrm{NaOH}$ and kept at $4{ }^{\circ} \mathrm{C}$ for $18 \mathrm{~h}$. The mixture was homogenized in an industrial blender at maximum speed (Osterizer, Wisconsin, USA) and passed first through cheesecloth to remove fibers and then through a 100-mesh sieve $(150 \mu \mathrm{m})$ (Advantech Manufacturing, Wisconsin, USA). The suspension was let sit for $18 \mathrm{~h}$. The supernatant was discarded and the retained solids washed three times to remove $\mathrm{NaOH}$. The supernatant removal process was aided by centrifugation $\left(13,698 \times g, 15 \mathrm{~min}, 8^{\circ} \mathrm{C}\right.$; Allegra 64R Centrifuge, Beckman Coulter, California, USA). The obtained starch was placed into plastic cylindrical trays $(16 \times 13 \times 6 \mathrm{~cm})$ and dried at $40^{\circ} \mathrm{C}$ for $24 \mathrm{~h}$. Finally, the starch was ground in a mortar, passed through a 100-mesh sieve and stored in sealed plastic bags at $25^{\circ} \mathrm{C}$ until use.

\subsection{Proximate analysis}

Proximate analysis of starches was conducted according to AOAC official methods 923.03, 920.35, 925.10 and 991.20 (Association of Official Analytical Chemists, 2002) to determine the ash, fat, moisture and protein content $(\mathrm{N} \times 6.25)$, respectively.

\subsection{Thermal properties}

The thermal properties of the starches were determined according to Sandhu et al. (2007). A starch sample (2 mg dry basis) was placed into a stainless steel pan, adding $7 \mu \mathrm{L}$ of distilled water. The pan was hermetically sealed and allowed to stand for $1 \mathrm{~h}$ to allow hydration. The thermal analysis was carried out using a differential scanning calorimeter (DSC 4000; PerkinElmer, Massachusetts, USA) using an empty pan as reference. Subsequently, the pans were heated from 20 to $120{ }^{\circ} \mathrm{C}$ at a heating rate of $5{ }^{\circ} \mathrm{C} \mathrm{min}-1$, under an inert nitrogen atmosphere at a rate of $50 \mathrm{~mL} \mathrm{~min}{ }^{-1}$. The onset temperature $\left(\mathrm{T}_{\mathrm{o}}\right)$, peak temperature $\left(\mathrm{T}_{\mathrm{p}}\right)$, end temperature $\left(\mathrm{T}_{\mathrm{c}}\right)$ and enthalpy $(\Delta \mathrm{H})$ of gelatinization were determined using the PerkinElmer Pyris Software 11.1.

\subsection{Tristimulus color}

The starch color was determined using a CR-300 Minolta colorimeter (Minolta, Tokyo, Japan) with diffuse lighting geometry, viewing angle of $0^{\circ}$ and an $8 \mathrm{~mm}$ port/viewing area. Prior to starch evaluation, the colorimeter was calibrated with a standard white. Each starch type (randomly) was evaluated five times $\left(L^{*}, a^{*}\right.$, and $\left.b^{\star}\right)$.

\subsection{Granule size and light microscopy}

The granule size was estimated in aqueous starch suspensions $(2 \%, w / w)$, an aliquot of $25 \mu \mathrm{L}$ of the suspension was placed on slides and cover slips and immediately analyzed in triplicate in an optical microscope (AxioScope.A1, Carl Zeiss, Jena, Germany) equipped with an AxioCam ICc1 camera. Measurements were taken of 20 starch granules per sample. The images were taken at $1,000 \mathrm{x}$ magnification, and the granule size was estimated using ZEN lite software. Likewise, micrographs at 400x magnification were taken with ordinary and polarized light and were used to observe the morphology of each corn starch.

\subsection{Fourier Transform Infrared Spectroscopy (FTIR)}

FTIR analysis of starches was performed following the methodology described by Zamudio-Flores et al. (2010). The FTIR spectra were recorded from 400 to $4,000 \mathrm{~cm}^{-1}$ with a resolution of $4 \mathrm{~cm}^{-1}$ for 34 scans by a spectrophotometer (Spectrum Two, PerkinElmer, Massachusetts, USA) equipped with a universal attenuated total reflectance (UATR) accessory.

\subsection{Rheological properties}

A suspension of each corn starch sample $(20 \%, w / w)$ was prepared. Rheological measurements, such as the storage modulus $\left(G^{\prime}\right)$, loss modulus $\left(G^{\prime \prime}\right)$ and loss factor $(\tan \delta)$, were determined from measurements within the linear visco-elastic region of each paste of the corn starches according to Sandhu et al. (2004), using a dynamic rheometer (AR 1500ex, TA Instruments, Delaware, USA) equipped with the stainless steel parallel plate geometry ( $60 \mathrm{~mm}$ diameter). The gap size was set at $1,000 \mu \mathrm{m}$, while the frequency and strain were set at $1 \mathrm{~Hz}$ and $0.5 \%$, respectively. The suspension was loaded on the Peltier plate and covered with a layer of low-density silicon oil. The samples were heated, starting at $45^{\circ} \mathrm{C}$ and increasing to $90^{\circ} \mathrm{C}$ at a rate of $2{ }^{\circ} \mathrm{C} \mathrm{min}^{-1}$. All measurements were made in triplicate.

\subsection{Water binding capacity}

The water binding capacity of the corn starches was determined according to the methodology described by Ashri et al. (2014) with modifications. Briefly, starch suspensions $(6.5 \%, \mathrm{w} / \mathrm{w})$ were prepared by stirring at $200 \mathrm{rpm}$ for $1 \mathrm{~h}$. Then, the suspensions were centrifuged $\left(822 \times g, 10 \mathrm{~min}, 8^{\circ} \mathrm{C}\right)$, and the supernatant was discarded. The solids were drained for $10 \mathrm{~min}$, and the water binding capacity was gravimetrically measured considering the weight of dried starch used for the suspension preparation and that of the wet starch after draining. 


\subsection{Amylose content}

The amylose content was determined in triplicate using an Amylose/Amylopectin K-AMYL 09/14 assay kit (Megazyme, International Ltd., Bray, Co. Wicklow, Ireland) based on the method using concanavalin.

\subsection{Light absorbance}

The light absorbance of the starches was evaluated according to Bello-Pérez et al. (1999) and Sandhu et al. (2004). A starch dispersion $(2 \%, \mathrm{w} / \mathrm{w})$ was heated at $90^{\circ} \mathrm{C}$ with constant stirring for $30 \mathrm{~min}$. The suspension was poured into disposable plastic cuvettes $(12.5 \times 12.5 \times 45 \mathrm{~mm}$; Brand, Wertheim, Germany $)$ and kept at $4{ }^{\circ} \mathrm{C}$ for $5 \mathrm{~d}$. The light absorbance was spectrophotometrically evaluated every $24 \mathrm{~h}$ for $120 \mathrm{~h}$ systematically at $640 \mathrm{~nm}$ (Evolution 300, Thermo Scientific, Massachusetts, USA). Distilled water was used as a blank.

\subsection{Statistical analysis}

The data were analyzed by a balanced analysis of variance (ANOVA) and Tukey's test $(p=0.05)$ using Statistical Analysis System software (SAS Institute, 2002).

\section{Results and discussion}

\subsection{Yield and proximate composition of isolated starches}

The hybrid corn showed the highest starch content, with its starch showing higher fat, moisture and protein contents than those of the tested corn landraces (Table 1). These starches obtained from hybrid corn could be classified and used as normal corn starches (Aparicio-Saguilán et al., 2004; Hardacre \& Clark, 2006). However, the composition of corn can be modified by plant breeding methods, to be used as food source and in the wet-milling and ethanol industries (Acton, 2013; Cauvain \& Young, 2009; Eckhoff \& Watson, 2009). In general, the proximate composition found in this study is similar to that reported for other corn starches (Ash $=0.1 \%$, Fat $=0.2$ to $0.5 \%$, Protein $=1.1$ to $2.0 \%$, Moisture $=6.5$ to $8.5 \%$ ) (Blanche $\&$ Sun, 2004; Tovar-Benítez, 2008). Likewise, it has been reported that low fat and protein contents indicate high purity of isolated starches (Tirado-Gallegos et al., 2016). Lipids and proteins in starch granules can increase their functionality; the protein in starch granules is associated with grain hardness, while the lipids can significantly reduce the swelling capacity of the starch paste. On the other hand, the presence of minerals in the starch has been related to the increase of clarity and viscosity of the paste. Likewise the low moisture content reduces the risk of microbial growth during storage (Alcázar-Alay \& Meireles, 2015; Yousif et al., 2012).

\subsection{Thermal properties}

The starch from the hybrid corn showed the lowest onset temperature of gelatinization $\left(\mathrm{T}_{\mathrm{o}}=65.6^{\circ} \mathrm{C}\right)$ among the tested starches (Table 2). These results are in agreement with the studies carried out by Li et al. (1994), where thirty-five corn varieties were analyzed, finding a mean $\mathrm{T}_{\mathrm{o}}$ value of $66.3^{\circ} \mathrm{C}$. The onset temperature represents the initiation of the gelatinization period and is related to the swelling of the granule. This could have important industrial implications because some companies justify the costs of their processes regarding energy and time, and if the starch requires less time and a lower temperature for gel formation, this implies a lower requirement of energy and time (Tester \& Debon, 2000). The peak temperature $\left(\mathrm{T}_{\mathrm{p}}\right)$, end temperature $\left(\mathrm{T}_{c}\right)$ and enthalpy $(\Delta \mathrm{H})$ of gelatinization were similar for all starches (Table 2). Values for $\mathrm{T}_{\mathrm{p}}$ were similar $\left(70.6\right.$ to $72.2^{\circ} \mathrm{C}$ ) to those reported for other corn starches (Sandhu \& Singh, 2007). High $\mathrm{T}_{\mathrm{p}}$ values have been related to a higher affinity of starch for water and starch crystallinity, influencing the texture and color properties of starch pastes, respectively (Díaz-Molina \& Carreras-Collazo, 1999; Wang et al., 2011). The gelatinization enthalpy values found for the three corn starches showed similarity to other studies ( 11.4 to $13.4 \mathrm{~J} \mathrm{~g}^{-1}$ ) of commercial corn starches (Amaya-Llano et al., 2011; Lewandowicz et al., 2000). Based on previous studies, it is inferred that the low $\Delta H$ values of starch from blue corn can be attributed to its small granule size. These $\Delta \mathrm{H}$ values are influenced by factors such as the granule shape and size and the degree of crystallinity of the starch (Cai et al., 2015). The thermal characterization of starch is important because this polysaccharide is submitted to several thermal transformation processes in industry.

\subsection{Tristimulus color}

The isolated starches were white, showing high $L$ values (93.6 to 99.5); however, starch from blue corn was less white (Table 1), probably as a consequence of residual anthocyanins (Agama-Acevedo et al., 2005). The tested starches were whiter

Table 1. Physicochemical properties of native corn starches.

\begin{tabular}{cccc}
\hline Physicochemical & \multicolumn{3}{c}{ Starch source } \\
\cline { 2 - 4 } properties & Blue corn & White corn & Hybrid corn \\
\hline Ash (\%) & $0.1 \pm 0.0^{\mathrm{a}}$ & $0.1 \pm 0.0^{\mathrm{a}}$ & $0.1 \pm 0.0^{\mathrm{a}}$ \\
Fat (\%) & $0.2 \pm 0.0^{\mathrm{b}}$ & $0.2 \pm 0.0^{\mathrm{b}}$ & $0.4 \pm 0.0^{\mathrm{a}}$ \\
Moisture (\%) & $6.5 \pm 0.1^{\mathrm{b}}$ & $6.9 \pm 0.0^{\mathrm{b}}$ & $8.5 \pm 0.1^{\mathrm{a}}$ \\
Protein (\%) & $1.1 \pm 0.1^{\mathrm{b}}$ & $1.2 \pm 0.2^{\mathrm{b}}$ & $2.0 \pm 0.2^{\mathrm{a}}$ \\
Yield (\%) & $16.9 \pm 0.7^{\mathrm{bc}}$ & $18.7 \pm 0.3^{\mathrm{b}}$ & $23.5 \pm 1.2^{\mathrm{a}}$ \\
Color & & & \\
$L$ & $93.6 \pm 0.2^{\mathrm{c}}$ & $99.5 \pm 0.0^{\mathrm{a}}$ & $98.4 \pm 0.2^{\mathrm{b}}$ \\
$a$ & $1.4 \pm 0.0^{\mathrm{a}}$ & $-0.4 \pm 0.0^{\mathrm{b}}$ & $-1.3 \pm 0.2^{\mathrm{c}}$ \\
$b$ & $0.9 \pm 0.1^{\mathrm{b}}$ & $0.2 \pm 0.0^{\mathrm{c}}$ & $2.9 \pm 0.3^{\mathrm{a}}$ \\
Approximate & $13.3 \pm 1.1^{\mathrm{b}}$ & $19.0 \pm 1.0^{\mathrm{a}}$ & $21.4 \pm 0.8^{\mathrm{a}}$ \\
granule size ( $\mu \mathrm{m})$ & & & \\
\hline Arithmetic mean \pm standard error. Values with the sameliteral between rows are statistically \\
equal according to the Tukey's test $(p=0.05)$. Averages of at least three measurements.
\end{tabular}

Table 2. Thermal variables of native corn starches.

\begin{tabular}{ccccc}
\hline \multicolumn{5}{c}{ Transition temperatures and gelatinization enthalpy for corn starch } \\
\hline Starch source & $\mathrm{T}_{\mathrm{o}}\left({ }^{\circ} \mathrm{C}\right)$ & $\mathrm{T}_{\mathrm{p}}\left({ }^{\circ} \mathrm{C}\right)$ & $\mathrm{T}_{\mathrm{c}}\left({ }^{\circ} \mathrm{C}\right)$ & $\Delta \mathrm{H}\left(\mathrm{J} \mathrm{g}^{-1}\right)$ \\
\hline Blue corn & $66.9 \pm 0.3^{\mathrm{ab}}$ & $71.6 \pm 0.1^{\mathrm{a}}$ & $79.8 \pm 0.2^{\mathrm{a}}$ & $11.4 \pm 0.8^{\mathrm{a}}$ \\
White corn & $67.5 \pm 0.2^{\mathrm{a}}$ & $72.2 \pm 0.1^{\mathrm{a}}$ & $80.9 \pm 0.1^{\mathrm{a}}$ & $13.4 \pm 0.8^{\mathrm{a}}$ \\
Hybrid corn & $65.6 \pm 0.7^{\mathrm{b}}$ & $70.6 \pm 0.6^{\mathrm{a}}$ & $79.2 \pm 0.6^{\mathrm{a}}$ & $12.9 \pm 1.0^{\mathrm{a}}$ \\
\hline $\mathrm{T}_{\mathrm{o}}=$ onset temperature; $\mathrm{T}_{\mathrm{p}}=$ peak temperature; $\mathrm{T}_{\mathrm{c}}=$ end temperature; $\Delta \mathrm{H}=$ Enthalpy of \\
gelatinization. Arithmetic mean \pm standard error. Values with the same letter between \\
columns are statistically equal according to the Tukey's test $(p=0.05)$. Averages of at \\
least three measurements.
\end{tabular}


than those of sorghum, rice and corn which showed $L$ values from 90.8 to 95.7 (Xie \& Seib, 2000; Lee \& Puligundla, 2016; Zhang et al., 2005). The color of finished starch is an important quality attribute, with white starches containing lower levels of proteins and pigments. Similarly, Sánchez-Rivera et al. (2005) emphasized that the whiteness is an important physical parameter of starches, as it determines their industrial applications in pharmaceutical, food and agricultural sectors, among others.

\subsection{Granule size and light microscopy}

The granules size varied among the starches, ranging from 13.3 to $21.4 \mu \mathrm{m}$ (Table 1). These results are within the range reported for corn starches ( 2 to $37 \mu \mathrm{m}$ ) (Agama-Acevedo et al., 2005; Blanche \& Sun, 2004; Tester et al., 2004). The size and shape of corn starch granules depend mainly on variety. In corn hybrid varieties, the structural differences could be related to the starch biosynthesis (Agama-Acevedo et al., 2008). On the other hand, it is seen that the starches showed a mixture of rounded and angular granules, which have been related to the granular form of the granules with a high content of amylopectin (Chen et al., 2006), likewise, the images obtained under polarized light were taken at the same position as the images under ordinary light, where it can observe centered hilums and polarization crosses (Figure 1). The particle size of the starch granules determines which starches can be incorporated into different composites or applications, for example, into some biodegradable plastic films if the dimensions of starch are small, as well as viscosity modification, binding, sizing and coating if the granule size is higher (Ellis et al., 1998).

\subsection{Fourier Transform Infrared Spectroscopy (FTIR)}

The starch fingerprint region $\left(1,250\right.$ to $\left.400 \mathrm{~cm}^{-1}\right)$ of the FTIR spectra was similar for the tested starches. The most intense peaks corresponded to carbohydrate vibrations, showing no apparent structural differences in the low range molecular order (Pelissari et al., 2012) (Figure 2). The peak observed at 1,640 $\mathrm{cm}^{-1}$ corresponded to tightly bound water molecules in the starches (Fang et al., 2004). The region between 1,200 and $800 \mathrm{~cm}^{-1}$ is characteristic of the $\mathrm{C}-\mathrm{O}$ and $\mathrm{C}-\mathrm{C}$ stretching and $\mathrm{C}-\mathrm{O}-\mathrm{C}$ deformation modes, associated with the glycosidic bond (Almeida et al., 2010). The spectra of starch samples showed a peak at $3,290 \mathrm{~cm}^{-1}$, which corresponded to symmetric and

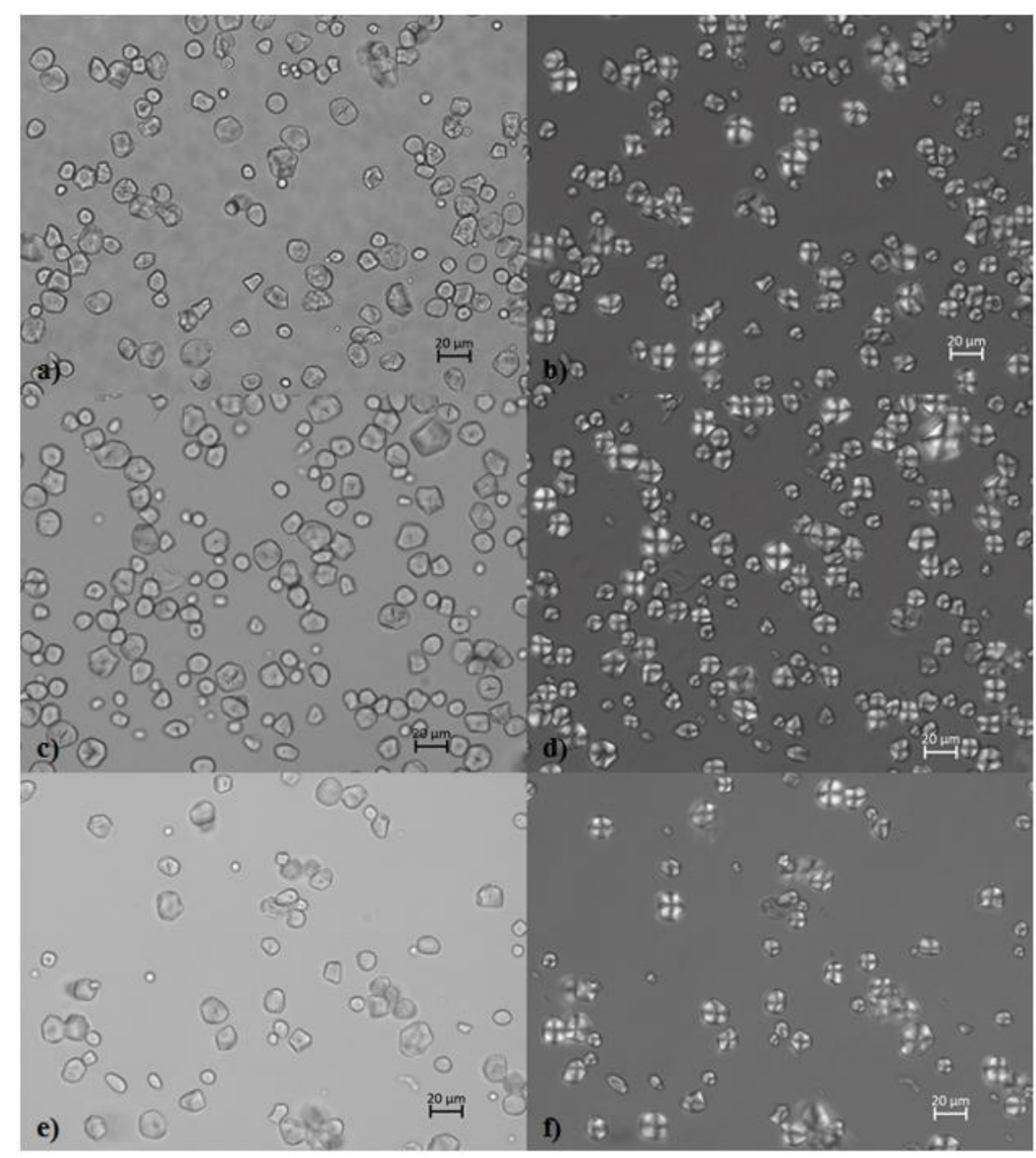

Figure 1. Micrographs of native corn starch granules observed under ordinary and polarized light, respectively. (a) and (b) Blue corn starch; (c) and (d) White corn starch; and (e) and (f) Hybrid corn starch. 


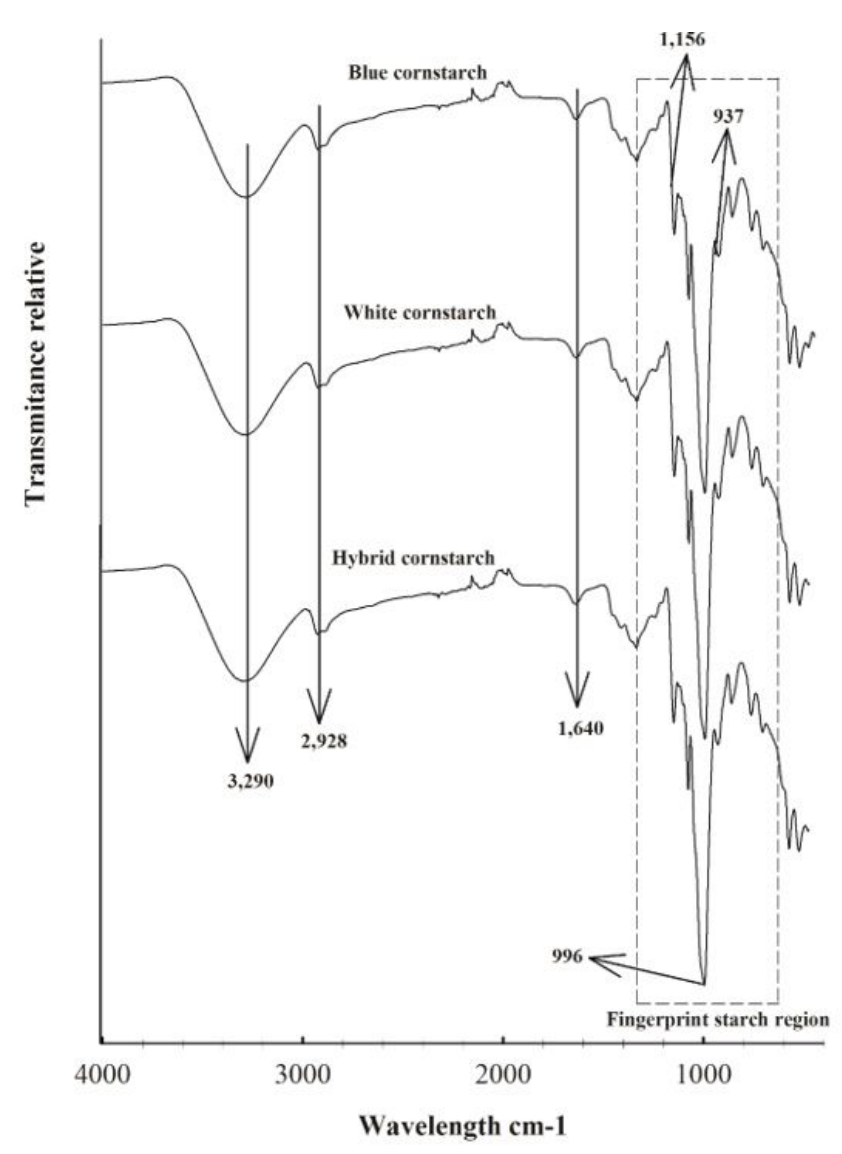

Figure 2. Fourier transform infrared spectroscopy of samples of native corn starches.

asymmetric stretching of O-H bonds (Pelissari et al., 2012). The peak at $2,928 \mathrm{~cm}^{-1}$ was attributed to $\mathrm{C}-\mathrm{H}$ bond stretching (Liu et al., 2011). The peaks observed between 937 and 1,156 $\mathrm{cm}^{-1}$ were attributed to C-O bond stretching (Fang et al., 2002). The sharp peak at $996 \mathrm{~cm}^{-1}$ was related to the crystallinity of the starch (Vicentini et al., 2005). The ratios $(R)$ of absorbance $1,047 / 1,022$ and $1,022 / 995 \mathrm{~cm}^{-1}$ were calculated and are shown in Figure 3. The starch of the hybrid corn showed the greatest $R(1,047 / 1,022)$, which expresses the amount of ordered to amorphous starch. Therefore, high $R$ values indicated a great level of ordered structure in the external region of the starch from hybrid corn (Yu et al., 2013). The $R$ of $1,022 / 995 \mathrm{~cm}^{-1}$ is used as a measure of the correlation of amorphous to ordered carbohydrate structure in the starch (Sevenou et al., 2002). Therefore, high values of $R$ could be interpreted as high resistance to breaking of the starch granule structure, either by enzymatic hydrolysis or by heat treatment influencing the gelatinization process.

\subsection{Rheological properties}

The rheological measurements of corn starches during heating are shown in Table 3. The temperature at $\mathrm{G}$ ' is maximum during heating ( $\mathrm{TG}$ ') showed significant differences, with starch from blue corn showing the greatest value $\left(71.2^{\circ} \mathrm{C}\right)$, followed by starch from white $\left(70.0^{\circ} \mathrm{C}\right)$ and hybrid corn $\left(67.1^{\circ} \mathrm{C}\right)$. The values for $G^{\prime}(6,410$ to $9,547 \mathrm{~Pa})$ and the loss

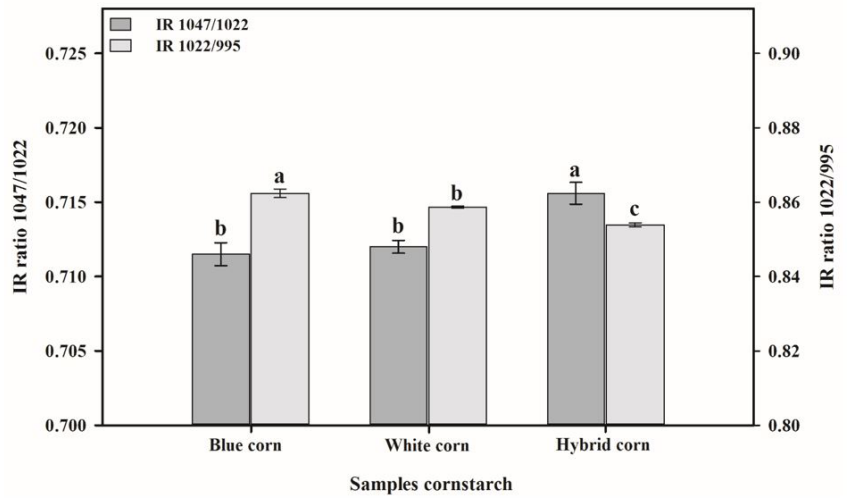

Figure 3. IR ratio of absorbance $1,047 / 1,020$ and $1,022 / 995 \mathrm{~cm}^{-1}$ of native corn starches.

Table 3. Rheological properties of native corn starches and their fractions during heating.

\begin{tabular}{|c|c|c|c|c|}
\hline $\begin{array}{l}\text { Starch } \\
\text { source }\end{array}$ & $\mathrm{T} G^{\prime}\left({ }^{\circ} \mathrm{C}\right)$ & Peak $G^{\prime}(\mathrm{Pa})$ & Peak G” $(\mathrm{Pa})$ & Peak $\tan \delta$ \\
\hline Blue corn & $71.2 \pm 0.0^{\mathrm{a}}$ & $7,012 \pm 542^{b}$ & $1,356 \pm 69^{b}$ & $0.19 \pm 0.0^{\mathrm{a}}$ \\
\hline White corn & $70.0 \pm 0.0^{\mathrm{b}}$ & $6,410 \pm 177^{b}$ & $1,556 \pm 205^{\mathrm{ab}}$ & $0.24 \pm 0.0^{\mathrm{a}}$ \\
\hline Hybrid corn & $67.1 \pm 0.1^{\mathrm{c}}$ & $9,547 \pm 270^{\mathrm{a}}$ & $1,950 \pm 141^{\mathrm{a}}$ & $0.20 \pm 0.0^{\mathrm{a}}$ \\
\hline
\end{tabular}

factor ( $\tan \delta ; 0.19$ to 0.24 ) were similar among the starches. These results are unlike those reported by Song et al. (2013), who found values for $G^{\prime}$ of 64,600 to $92,400 \mathrm{~Pa}$ in a mixture of surimi and native corn starches. Likewise, the values found in this study were higher than values of $G$ ' and $G$ " for different corn starches reported by Sandhu et al. (2004). For all three starches, the value of $G^{\prime}$ was higher than that of $G$ ", which is an indication that the elastic properties were higher than the properties related to viscosity; this attribute allows the native starch to be commonly used as an enhancer of texture and elasticity, mainly in sausages (Song et al., 2013). Figure $4 \mathrm{a}$ and b show $G$ ' and $G$ " reaching the maximum heating value, giving origin to the rupture of the granule ordering and therefore the gel formation of suspensions of corn starches during heating.

\subsection{Water Binding Capacity (WBC)}

The WBCs for the tested starches are shown in Table 4. The hybrid corn starch showed the highest WBC (106.2\%), followed by the starches from the white (103.9\%) and blue corn (89.6\%). These values were higher than those (82 to 98\%) of lentil, fava bean, field pea and other corn starches (Hoover \& Sosulski, 1986; Sandhu et al., 2007). The differences found for WBCs of starches may be a consequence of variations in size and structure of the granules (Sandhu et al., 2004). Our results suggest that the blue corn starch formed many hydroxyl groups through hydrogen bonds between starch chains because it presented a smaller capacity of water retention. Additionally, a high WBC 
value could be attributed to a greater number of available binding sites for water in starch granules, influencing the gelatinization process, since this process requires an interaction between the water molecules and the starch (Sandhu et al., 2007).

\subsection{Amylose content}

The amylose contents were similar in the tested starches (21.5 to $22.4 \%$ ) (Table 4 ) and similar to those reported (15.5 to $27.5 \%$ ) for barley starches but lower than those of white (25.5\%) and yellow (25.9\%) corn starch (Cisse et al., 2013; Chávez-Murillo et al., 2008). These values are important parameters because the physical properties of starches
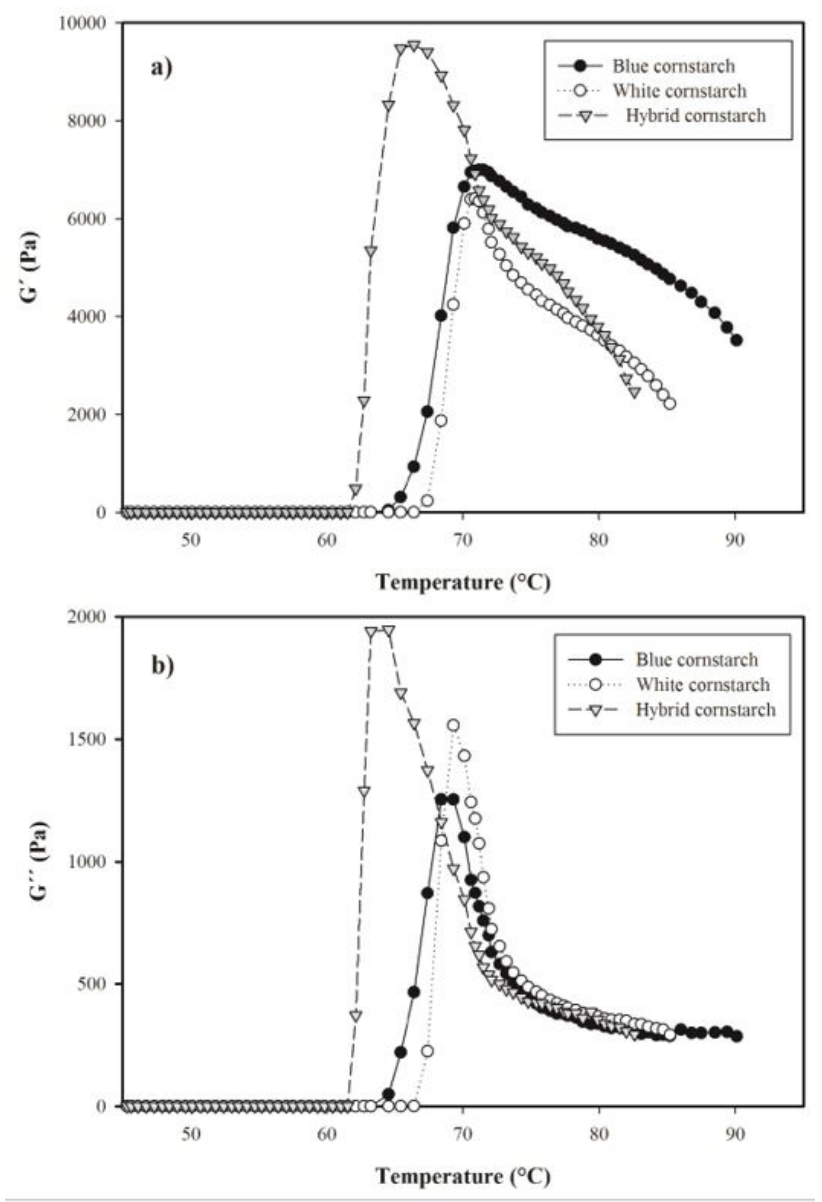

Figure 4. (a) Storage modulus $\left(G^{\prime}\right)$ and (b) Loss modulus $\left(G^{\prime \prime}\right)$ of gels of native corn starches. are determined by the amylose and amylopectin content (Fredriksson et al., 1998). Likewise, amylose has been correlated with hardness and gumminess, influencing the texture of various products (Sandhu \& Singh, 2007).

\subsection{Light absorbance}

The light absorbance of the starch gels increased with storage time, with the higher absorbance observed after 120 $\mathrm{h}$ for all corn starches (2.5 to 2.7) (Table 4). The initial light absorbance was higher than that observed by Sandhu \& Singh (2007) for other corn starches after storage for $120 \mathrm{~h}$. The light absorbance of the starch dispersions was also higher than that reported for dispersions of rice starches (Kaur et al., 2002). The light absorbance increase is attributed to granule swelling, granule remnants and amylose and amylopectin chain length, so this could be indicative of amylose crystallization. On the other hand, the increase in light absorbance indicates changes in refractive index and density, influencing the rheological behavior of the gel (Ring et al., 1987).

\section{Conclusions}

Differences in the chemical composition, thermal properties and granule size may be due to genetic differences between corn varieties. The low content of fat and proteins in the chemical composition of the starches indicates their high purity. The hybrid corn starch showed better yield than the two corn landraces. All corn starches showed greatest values of brightness $(L)$ and lower $a$ and $b$, as a result of lower levels of associated components such as pigments. The thermal properties $\mathrm{T}_{\mathrm{o}}, \mathrm{T}_{\mathrm{p}}$ and $\mathrm{T}_{\mathrm{c}}$ of hybrid corn starch were lower than those of the blue and white corn starches. The chemical composition and thermal and rheological properties of corn starches are parameters that must be known to enable possible use as an encapsulating agent in the food, pharmaceutical, and agricultural industries, among other products.

\section{Acknowledgements}

The author (J. C. Bustillos Rodríguez) thanks the Consejo Nacional de Ciencia y Tecnología (CONACYT-México) for the scholarship provided during his $\mathrm{PhD}$ study in the Centro de Investigación en Alimentación y Desarrollo A.C. This work was supported by the Secretaría de Agricultura, Ganadería, Desarrollo Rural, Pesca y Alimentación (SAGARPA-COFUPRO, México) [CH1600001442].

Table 4. Water binding capacity, amylose content and light absorbance of native corn starches.

\begin{tabular}{|c|c|c|c|c|c|c|c|c|}
\hline \multirow{2}{*}{ Starch source } & \multirow{2}{*}{$\begin{array}{l}\text { Water binding } \\
\text { capacity (\%) }\end{array}$} & \multirow{2}{*}{ Amylose (\%) } & \multicolumn{6}{|c|}{ Light absorbance $(640 \mathrm{~nm})$} \\
\hline & & & $0 \mathrm{~h}$ & $24 \mathrm{~h}$ & $48 \mathrm{~h}$ & $72 \mathrm{~h}$ & $96 \mathrm{~h}$ & $120 \mathrm{~h}$ \\
\hline Blue corn & $89.6 \pm 3.3^{\mathrm{b}}$ & $22.4 \pm 1.6^{\mathrm{a}}$ & $2.3 \pm 0.2^{\mathrm{a}}$ & $2.5 \pm 0.0^{\mathrm{a}}$ & $2.6 \pm 0.1^{\mathrm{a}}$ & $2.7 \pm 0.0^{\mathrm{a}}$ & $2.7 \pm 0.0^{\mathrm{a}}$ & $2.7 \pm 0.0^{\mathrm{a}}$ \\
\hline White corn & $103.9 \pm 3.3^{\mathrm{a}}$ & $21.9 \pm 5.7^{\mathrm{a}}$ & $2.3 \pm 0.0^{\mathrm{a}}$ & $2.3 \pm 0.0^{\mathrm{b}}$ & $2.5 \pm 0.0^{\mathrm{ab}}$ & $2.4 \pm 0.0^{\mathrm{b}}$ & $2.5 \pm 0.0^{\mathrm{b}}$ & $2.5 \pm 0.0^{\mathrm{b}}$ \\
\hline Hybrid corn & $106.2 \pm 3.2^{\mathrm{a}}$ & $21.5 \pm 2.9^{\mathrm{a}}$ & $1.9 \pm 0.0^{\mathrm{b}}$ & $2.2 \pm 0.0^{c}$ & $2.3 \pm 0.0^{\mathrm{b}}$ & $2.4 \pm 0.0^{\mathrm{b}}$ & $2.4 \pm 0.0^{c}$ & $2.5 \pm 0.0^{\mathrm{b}}$ \\
\hline
\end{tabular}

Arithmetic mean \pm standard error. Values with the same literal between columns are statistically equal according to the Tukey's test ( $p=0.05)$. Averages of at least three measurements. 


\section{References}

Acton, Q. (2013). Advances in intracellular space research and application. Atlanta: Scholarly Brief.

Agama-Acevedo, E., de la Rosa, A. P. B., Méndez-Montealvo, G., \& BelloPérez, L. A. (2008). Physicochemical and biochemical characterization of starch granules isolated of pigmented maize hybrids. Stärke, 60(8), 433-441. http://dx.doi.org/10.1002/star.200800206.

Agama-Acevedo, E., Ottenhof-Astrid, M., Farhat, I. A., Paredes-López, O., Ortiz-Cereceres, J., \& Bello-Pérez, L. A. (2005). Aislamiento y caracterización del almidón de maíces pigmentados. Agrociencia, 39(4), 419-429. Retrieved from http://www.redalyc.org/articulo. oa? $\mathrm{id}=30239406$

Alcázar-Alay, S. C., \& Meireles, M. A. A. (2015). Physicochemical properties, modifications and applications of starches from different botanical sources. Food Science and Technology, 35(2), 215-236. http://dx.doi.org/10.1590/1678-457X.6749.

Almeida, M. R., Alves, R. S., Nascimbem, L. B., Stephani, R., Poppi, R., \& de Oliveira, L. F. (2010). Determination of amylose content in starch using Raman spectroscopy and multivariate calibration analysis. Analytical and Bioanalytical Chemistry, 397(7), 2693-2701. http://dx.doi.org/10.1007/s00216-010-3566-2. PMid:20213166.

Álvares-Buylla, E. (2004). Alimentos transgénicos. In J. M. Rubio (Ed.), Transgenic food: ciencia, ambiente y mercado: un debate abierto. Ciudad de México: Ediciones Siglo XXI.

Amaya-Llano, S. L., Martínez-Bustos, F., Martínez Alegría, A. L., \& Jesús Zazueta-Morales, J. (2011). Comparative studies on some physico-chemical, thermal, morphological, and pasting properties of acid-thinned jicama and maize starches. Food and Bioprocess Technology, 4(1), 48-60. http://dx.doi.org/10.1007/s11947-008-0153-z.

Aparicio-Saguilán, A., Méndez-Montealvo, G., Solorza-Feria, J., \& Bello-Pérez, L. (2004). Thermal and rheological profile of corn starch from different varieties. In V. P. Yuryev, P. Tomasik \& H. Ruck (Eds.), Starch: from polysaccharides to granules, simple and mixture gels (pp. 187-194). New York: Nova Science Publishers.

Ashri, A., Yusof, M. S. M., Jamil, M. S., Abdullah, A., Yusoff, S. F. M., Arip, M. N. M., \& Lazim, A. M. (2014). Physicochemical characterization of starch extracted from Malaysian wild yam (Dioscorea hispida Dennst.). Emirates Journal of Food and Agriculture, 26(8), 652-658. http://dx.doi.org/10.9755/ejfa.v26i8.17098.

Association of Official Analytical Chemists - AOAC. (2002). Official methods of analysis of the Association of Official Analytical Chemists. Arlington: AOAC.

Bello-Pérez, L. A., Agama-Acevedo, E., Sánchez-Hernández, L., \& Paredes-López, O. (1999). Isolation and partial characterization of banana starches. Journal of Agricultural and Food Chemistry, 47(3), 854-857. http://dx.doi.org/10.1021/jf980828t. PMid:10552380.

Blanche, S., \& Sun, X. (2004). Physical characterization of starch extrudates as a function of melting transitions and extrusion conditions. Advances in Polymer Technology, 23(4), 277-290. http:// dx.doi.org/10.1002/adv.20017.

Cai, J., Cai, C., Man, J., Xu, B., \& Wei, C. (2015). Physicochemical properties of ginkgo kernal starch. International Journal of Food Properties, 18(2), 380-391. http://dx.doi.org/10.1080/10942912.2 013.831443 .

Cauvain, S. P., \& Young, L. S. (2009). The ICC handbook of cereals, flour, dough \& product testing: methods and applications. Lancaster: DEStech Publications.

Chávez-Murillo, C. E., Wang, Y. J., \& Bello-Pérez, L. A. (2008). Morphological, physicochemical and structural characteristics of oxidized barley and corn starches. Stärke, 60(11), 634-645. http:// dx.doi.org/10.1002/star.200800016.

Chen, P., Yu, L., Chen, L., \& Li, X. (2006). Morphology and microstructure of maize starches with different amylose/amylopectin content. Stärke, 58(12), 611-615. http://dx.doi.org/10.1002/star.200500529.

Cisse, M., Zoue, L. T., Soro, Y. R., Meganaou, R., \& Miamke, S. (2013). Physicochemical and functional properties of starches of two quality protein maize (QPM) grown in Côte d'Ivoire. Journal of Applied Biosciences, 66(0), 5130-5139. http://dx.doi.org/10.4314/ jab.v66i0.95010.

Copeland, L., Blazek, J., Salman, H., \& Tang, M. C. (2009). Form and functionality of starch. Food Hydrocolloids, 23(6), 1527-1534. http:// dx.doi.org/10.1016/j.foodhyd.2008.09.016.

Díaz-Molina, M., \& Carreras-Collazo, I. (1999). Síntesis y caracterización del almidón oxidado para su posterior evaluación como agente aglutinante en tabletas. Revista Cubana de Farmacia, 33(2), 98103. Retrieved from http://scielo.sld.cu/scielo.php?pid=S003475151999000200003\&script=sci_arttext\&tlng=pt

Eckhoff, S., \& Watson, S. (2009). Corn and sorghum starches: production. In J. BeMiller \& R. Whistler (Eds.), Starch: chemistry and technology (3rd ed., pp. 373-439). USA: Academic Press. http:// dx.doi.org/10.1016/B978-0-12-746275-2.00009-4.

Eliasson, A. C. (2004). Starch in food: structure, function and applications (1st ed.). USA: Taylor \& Francis.

Ellis, R. P., Cochrane, M. P., Dale, M. F. B., Duffus, C. M., Lynn, A., Morrison, I. M., Prentice, R. D. M., Swanston, J. S., \& Tiller, S. A. (1998). Starch production and industrial use. Journal of the Science of Food and Agriculture, 77(3), 289-311. http://dx.doi.org/10.1002/ (SICI) 1097-0010(199807)77:3<289::AID-JSFA38>3.0.CO;2-D.

Fang, J. M., Fowler, P. A., Sayers, C., \& Williams, P. A. (2004). The chemical modification of a range of starches under aqueous reaction conditions. Carbohydrate Polymers, 55(3), 283-289. http://dx.doi. org/10.1016/j.carbpol.2003.10.003.

Fang, J., Fowler, P., Tomkinson, J., \& Hill, C. (2002). The preparation and characterisation of a series of chemically modified potato starches. Carbohydrate Polymers, 47(3), 245-252. http://dx.doi.org/10.1016/ S0144-8617(01)00187-4.

Food and Agriculture Organization of the United Nations - FAO. (2016). Introducción al maíz y su importancia. Rome: FAO. Retrieved from http://www.fao.org/docrep/003/x7650s/x7650s02.htm

Fredriksson, H., Silverio, J., Andersson, R., Eliasson, A.-C., \& Åman, P. (1998). The influence of amylose and amylopectin characteristics on gelatinization and retrogradation properties of different starches. Carbohydrate Polymers, 35(3), 119-134. http://dx.doi.org/10.1016/ S0144-8617(97)00247-6.

García, N. L., Famá, L., Dufresne, A., Aranguren, M., \& Goyanes, S. (2009). A comparison between the physico-chemical properties of tuber and cereal starches. Food Research International, 42(8), 976982. http://dx.doi.org/10.1016/j.foodres.2009.05.004.

Hardacre, A. K., \& Clark, S. M. (2006). The effect of hybrid and growing environment on the rheological properties of starch and flour from maize (Zea mays L.) grain dried at four temperatures. International Journal of Food Science \& Technology, 41(s2), 144-150. http://dx.doi. org/10.1111/j.1365-2621.2006.01471.x.

Hoover, R., \& Sosulski, F. (1986). Effect of Cross-Linking on Functional Properties of Legume Starches. Stärke, 38(5), 149-155. http://dx.doi. org/10.1002/star.19860380502.

Idikut, L., Atalay, A., Kara, S., \& Kamalak, A. (2009). Effect of hybrid on starch, protein and yields of maize grain. Journal of Animal and 
Veterinary Advances, 8(10), 1945-1947. Retrieved from http://www. medwellonline.net/fulltext

Jobling, S. (2004). Improving starch for food and industrial applications. Current Opinion in Plant Biology, 7(2), 210-218. http://dx.doi. org/10.1016/j.pbi.2003.12.001. PMid:15003223.

Kaur, L., Singh, N., \& Sodhi, N. S. (2002). Some properties of potatoes and their starches II. Morphological, thermal and rheological properties of starches. Food Chemistry, 79(2), 183-192. http://dx.doi. org/10.1016/S0308-8146(02)00130-9.

Lee, Y. T., \& Puligundla, P. (2016). Characteristics of reduced-fat muffins and cookies with native and modified rice starches. Emirates Journal of Food and Agriculture, 28(5), 311-316. http://dx.doi.org/10.9755/ ejfa.2015-05-227.

Lewandowicz, G., Jankowski, T., \& Fornal, J. (2000). Effect of microwave radiation on physico-chemical properties and structure of cereal starches. Carbohydrate Polymers, 42(2), 193-199. http://dx.doi. org/10.1016/S0144-8617(99)00155-1.

Li, J., Berke, T., \& Glover, D. (1994). Variation for thermal properties of starch in tropical maize germ plasm. Cereal Chemistry, 71(1), 87-90. Retrieved from https://www.aaccnet.org/publications/cc/ backissues/1994/Documents/71_87.pdf

Liu, Q., Charlet, G., Yelle, S., \& Arul, J. (2002). Phase transition in potato starch-water system I. Starch gelatinization at high moisture level. Food Research International, 35(4), 397-407. http://dx.doi. org/10.1016/S0963-9969(01)00134-X.

Liu, T. Y., Ma, Y., Yu, S. F., Shi, J., \& Xue, S. (2011). The effect of ball milling treatment on structure and porosity of maize starch granule. Innovative Food Science \& Emerging Technologies, 12(4), 586-593. http://dx.doi.org/10.1016/j.ifset.2011.06.009.

Pelissari, F. M., Andrade-Mahecha, M. M., Sobral, P. J. A., \& Menegalli, F. C. (2012). Isolation and characterization of the flour and starch of plantain bananas (Musa paradisiaca). Stärke, 64(5), 382-391. http:// dx.doi.org/10.1002/star.201100133.

Ring, S. G., Colonna, P., I’Anson, K. J., Kalichevsky, M. T., Miles, M. J., Morris, V. J., \& Orford, P. D. (1987). The gelation and crystallisation of amylopectin. Carbohydrate Research, 162(2), 277-293. http:// dx.doi.org/10.1016/0008-6215(87)80223-9.

Sánchez-Rivera, M. M., García-Suárez, F. J. L., Velázquez del Valle, M., Gutierrez-Meraz, F., \& Bello-Pérez, L. (2005). Partial characterization of banana starches oxidized by different levels of sodium hypochlorite. Carbohydrate Polymers, 62(1), 50-56. http://dx.doi.org/10.1016/j. carbpol.2005.07.005.

Sandhu, K. S., \& Singh, N. (2007). Some properties of corn starches II: Physicochemical, gelatinization, retrogradation, pasting and gel textural properties. Food Chemistry, 101(4), 1499-1507. http:// dx.doi.org/10.1016/j.foodchem.2006.01.060.

Sandhu, K. S., Singh, N., \& Kaur, M. (2004). Characteristics of the different corn types and their grain fractions: physicochemical, thermal, morphological, and rheological properties of starches. Journal of Food Engineering, 64(1), 119-127. http://dx.doi.org/10.1016/j. jfoodeng.2003.09.023.

Sandhu, K. S., Singh, N., \& Lim, S.-T. (2007). A comparison of native and acid thinned normal and waxy corn starches: Physicochemical, thermal, morphological and pasting properties. LebensmittelWissenschaft + Technologie, 40(9), 1527-1536. http://dx.doi. org/10.1016/j.lwt.2006.12.012.

SAS Institute. (2002). SAS user's guide (version 9.0). Cary: SAS Institute.

Sevenou, O., Hill, S., Farhat, I., \& Mitchell, J. (2002). Organisation of the external region of the starch granule as determined by infrared spectroscopy. International Journal of Biological Macromolecules, 31(1-3), 79-85. http://dx.doi.org/10.1016/S0141-8130(02)00067-3. PMid:12559430.

Singh, N., Singh, J., Kaur, L., Singh Sodhi, N., \& Singh Gill, B. (2003). Morphological, thermal and rheological properties of starches from different botanical sources. Food Chemistry, 81(2), 219-231. http:// dx.doi.org/10.1016/S0308-8146(02)00416-8.

Smith, C. W. (2004). Corn, strange and marvelous: but is a deninitive origin known? In C. W. Smith, J. Betrán \& E. C. A. Runge (Eds.), Corn: origin, history, technology, and production (pp. 37). Hoboken: John Wiley.

Song, C.-G., Baik, M.-Y., \& Kim, B.-Y.. (2013). Rheological properties of native maize, waxy maize, and acetylated maize starches, and applications in the development of food products. Journal of the Korean Society for Applied Biological Chemistry, 56(1), 63-68. http:// dx.doi.org/10.1007/s13765-012-2142-1.

Tester, R. F., \& Debon, S. J. J. (2000). Annealing of starch: a review. International Journal of Biological Macromolecules, 27(1), 1-12. http://dx.doi.org/10.1016/S0141-8130(99)00121-X. PMid:10704980.

Tester, R. F., Karkalas, J., \& Qi, X. (2004). Starch: composition, fine structure and architecture. Journal of Cereal Science, 39(2), 151-165. http://dx.doi.org/10.1016/j.jcs.2003.12.001.

Tirado-Gallegos, J. M., Zamudio-Flores, P. B., Ornelas-Paz, J. J., RiosVelasco, C., Acosta-Muñiz, C. H., Gutiérrez-Meraz, F., Islas-Hernández, J. J., \& René, S.-D. (2016). Efecto del método de aislamiento y el estado de madurez en las propiedades fisicoquímicas, estructurales y reológicas de almidón de manzana. Revista Mexicana de Ingeniería Química, 15(2), 391-408. Retrieved from https://www.redalyc.org/ pdf/620/62046829008.pdf

Tovar-Benítez, T. (2008). Caracterización morfológica y térmica del almidón de maíz (Zea mays L.) obtenido por diferentes métodos de aislamiento (Tesis de licenciatura). Universidad Autónoma del Estado de Hidalgo, Hidalgo.

Uarrota, V. G., Amante, E. R., Demiate, I. M., Vieira, F., Delgadillo, I., \& Maraschin, M. (2013). Physicochemical, thermal, and pasting properties of flours and starches of eight Brazilian maize landraces (Zea mays L.). Food Hydrocolloids, 30(2), 614-624. http://dx.doi. org/10.1016/j.foodhyd.2012.08.005.

Vicentini, N., Dupuy, N., Leitzelman, M., Cereda, M., \& Sobral, P. (2005). Prediction of cassava starch edible film properties by chemometric analysis of infrared spectra. Spectroscopy Letters, 38(6), 749-767. http://dx.doi.org/10.1080/00387010500316080.

Wang, L., \& Wang, Y. J. (2001). Comparison of protease digestion at neutral $\mathrm{pH}$ with alkaline steeping method for rice starch isolation. Cereal Chemistry, 78(6), 690-692. http://dx.doi.org/10.1094/ CCHEM.2001.78.6.690.

Wang, Y., Zhang, L., Li, X., \& Gao, W. (2011). Physicochemical properties of starches from two different yam (Dioscorea opposita Thunb.) residues. Brazilian Archives of Biology and Technology, 54(2), 243251. http://dx.doi.org/10.1590/S1516-89132011000200004.

Waterschoot, J., Gomand, S. V., Fierens, E., \& Delcour, J. A. (2015). Production, structure, physicochemical and functional properties of maize, cassava, wheat, potato and rice starches. Stärke, 67(1-2), 14-29. http://dx.doi.org/10.1002/star.201300238.

Xie, X., \& Seib, P. (2000). Laboratory procedure to wet-mill $100 \mathrm{~g}$ of grain sorghum into six fractions 1. Cereal Chemistry, 77(3), 392-395. http://dx.doi.org/10.1094/CCHEM.2000.77.3.392.

Yousif, E., Gadallah, M., \& Sorour, A. M. (2012). Physico-chemical and rheological properties of modified corn starches and its effect on 
noodle quality. Annals of Agricultural Science, 57(1), 19-27. http:// dx.doi.org/10.1016/j.aoas.2012.03.008.

Yu, H., Cheng, L., Yin, J., Yan, S., Liu, K., Zhang, F., Xu, B., \& Li, L. (2013). Structure and physicochemical properties of starches in lotus (Nelumbo nucifera Gaertn.) rhizome. Food Science \& Nutrition, 1(4), 273-283. http://dx.doi.org/10.1002/fsn3.37. PMid:24804031.

Zamudio-Flores, P. B., Vargas-Torres, A., Gutiérrez-Meraz, F., \& BelloPérez, L. A. (2010). Caracterización fisicoquímica de almidones doblemente modificados de plátano. Agrociencia, 44(3), 283-295.
Retrieved from http://www.scielo.org.mx/scielo.php?pid=S140531952010000300004\&script=sci_arttext\&tlng=en

Zehr, B., Eckhoff, S., Singh, S., \& Keeling, P. (1995). Comparison of wet-milling properties among maize inbred lines and their hybrids. Cereal Chemistry, 72(5), 491-497. Retrieved from http://www.aaccnet. org/publications/cc/backissues/1995/Documents/72_491.pdf

Zhang, Z., Niu, Y., Eckhoff, S. R., \& Feng, H. (2005). Sonication enhanced cornstarch separation. Stärke, 57(6), 240-245. http:// dx.doi.org/10.1002/star.200400285. 